CZASOPISMO INŻYNIERII LĄDOWEJ, ŚRODOWISKA I ARCHITEKTURY JOURNAL OF CIVIL ENGINEERING, ENVIRONMENT AND ARCHITECTURE

JCEEA, t. XXXIV, z. 64 (1/17), styczeń-marzec 2017, s. 505-515, DOI:10.7862/rb.2017.46

\author{
Bartosz MILLER ${ }^{1}$ \\ Grzegorz PIĄTKOWSKI ${ }^{2}$ \\ Dominika ZIAJA ${ }^{3}$ \\ Leonard ZIEMIAŃSKI ${ }^{4}$
}

\title{
DYNAMIC MEASUREMENTS OF GROT-ROWECKI BRIDGE IN WARSAW
}

\begin{abstract}
The paper precisely describes the measurement set-up, location of all measurement and excitation points used during the dynamic measurements of Grot-Rowecki Bridge in Warsaw, Poland. Measurement equipment as well as all the obtained results in a form of pairs of related eigenfrequencies and eigenforms are presented in this article.
\end{abstract}

Keywords: dynamics, modal analysis, steel bridge

\section{Introduction}

The Grot-Rowecki Bridge is actually a set of two identical steel bridges, each allowing traffic in opposite direction. The north bridge is in reconstruction since 2009, apart from renewal and repair the bridge deck will be expanded by two additional traffic lanes located on a new cantilevers on both sides of the original bridge. The need to install additional parts caused many questions about their behavior (strength, serviceability). It was required to determine e.g. the fatigue strength of the connection between rib, girder, deck plate and the attached new element.

The paper presents measurements of the dynamic characteristics of a selected part of reconstructed bridge, commissioned in order to provide information to other research. During the measurements the bridge was still under reconstruction, e.g. the cantilevers for new lanes were not installed on

\footnotetext{
${ }^{1}$ Autor do korespondencji / corresponding author: Bartosz Miller, Politechnika Rzeszowska, al. Powstańców Warszawy 12, 35-959 Rzeszów, tel. (0-17)8651532, bartosz.miller@ prz.edu.pl

${ }^{2}$ Grzegorz Piątkowski, Politechnika Rzeszowska, al. Powstańców Warszawy 12, 35-959 Rzeszów, tel. (0-17)8651494, pgrzes@ prz.edu.pl

${ }^{3}$ Dominika Ziaja, Politechnika Rzeszowska, al. Powstańców Warszawy 12, 35-959 Rzeszów, tel. (0-17)8651618, dziaja@prz.edu.pl

${ }^{4}$ Leonard Ziemiański, Politechnika Rzeszowska, al. Powstańców Warszawy 12, 35-959 Rzeszów, tel. (0-17)8651353, ziele@ prz.edu.pl
} 
a whole bridge and the bituminous surface was not yet spread. The measurements were performed only on one, repeatable (with some major changes) section of the bridge, with the cantilevers already attached. The aim of examination was to receive frequencies and damping coefficients of one appointed bridge section and determination of displacement of cantilever part of the bridge.

The measured signals were recorded in 24 measurement points, the vibrations were excited either by a $5 \mathrm{~kg}$ modal hammer or by a passing of a $32000 \mathrm{~kg}$ truck (going in turns in both directions, with different speeds). The measured values were accelerations and, in case of application of modal hammer, also the excitation force. The obtained signals were analyzed and the frequencies and forms of one bridge section were obtained.

\section{The measurement set-up and the measurements}

\subsection{The excitation}

The vibrations of the bridge and/or its elements were excited by a modal hammer or by a passing truck. The modal hammer applied was a PCB Piezotronics $5.5 \mathrm{~kg}$ hammer type 086D50, with the sensitivity of $0.23 \mathrm{mV} / \mathrm{N}$ and hard or soft tip (both were applied during the measurements).

The impulse excitation was applied in $\mathrm{Z}$ direction (vertical), in turns in six points shown in Fig. 1. Each saved measurement was an average of 10 auxiliary measurements, each being measured after separate impulse excitation. The number of auxiliary measurements averaged to give one final measurement was an implication of the time constrains, since the dynamic measurements had do be performed in the gaps between consequent static tests.

The other excitation type was a passing $32000 \mathrm{~kg}$ truck, see Fig 2. During the measurements the truck was passing through the bridge section being observed with different velocities, directions, with constant velocity or braking sharply. The vibrations of the bridge were recorded during 12 passes, among them 5 in the east direction (velocities: $5 \mathrm{~km} / \mathrm{h}, 10 \mathrm{~km} / \mathrm{h}, 30 \mathrm{~km} / \mathrm{h}, 40 \mathrm{~km} / \mathrm{h}$ and $50 \mathrm{~km} / \mathrm{h}$ ), 5 in the west direction (velocities as above), one in reverse gear in the east direction and one in the east direction with sharp braking.

\subsection{Measuring equipment}

The measuring set-up consisted of a recorder/analyser and 24 accelerometers. As a recorder/analyser multi-channel Scadas Mobile by LMS International was applied (see Fig. 3), giving the possibility to conduct both experimental and operational modal analysis $[1,2]$ using PolyMAX algorithm. 


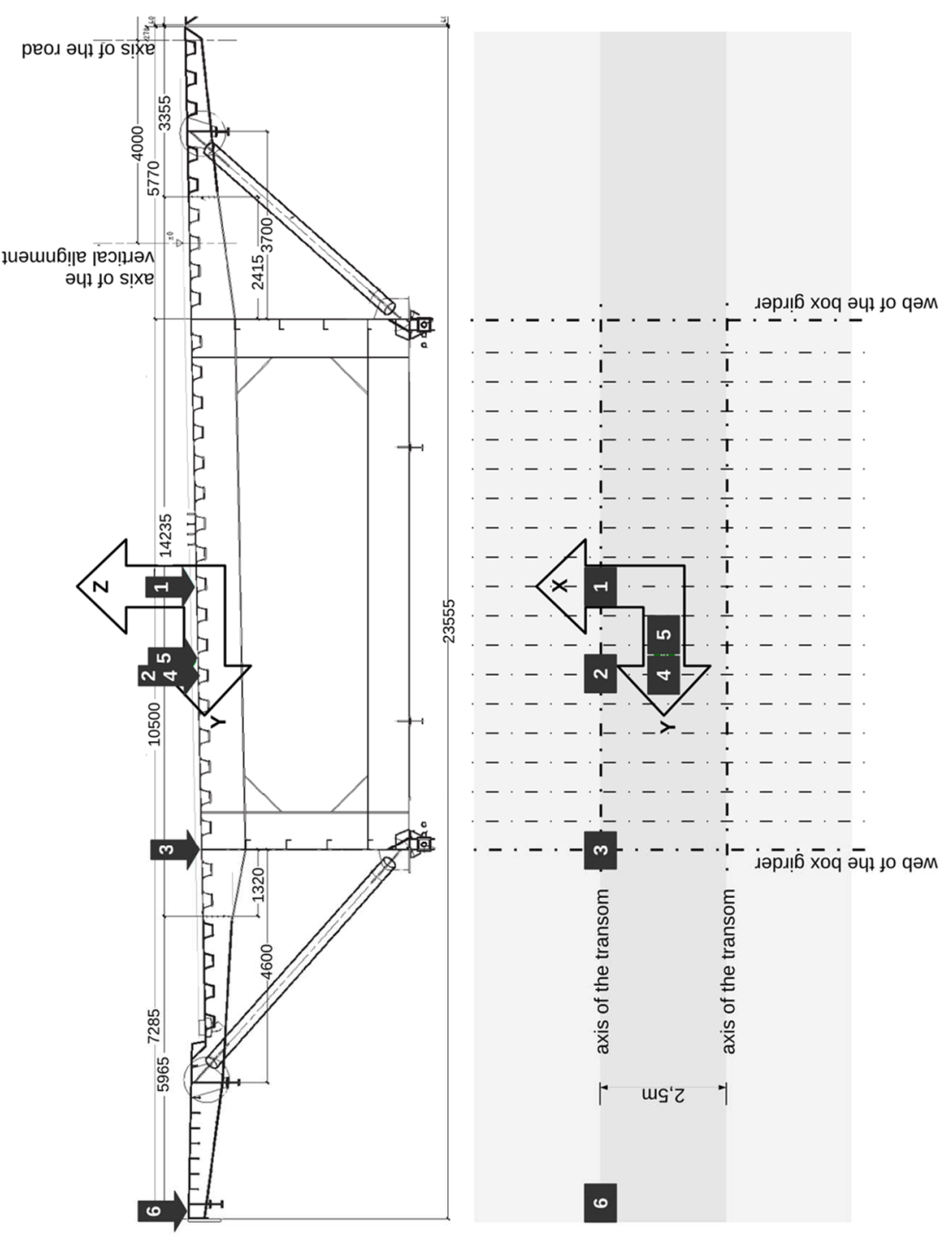

Rys. 1. Lokalizacja punktów wymuszenia (wymuszenie młotkiem modalnym)

Fig. 1. Impulse excitation points

The recorded acceleration signals after the transformation into the frequency domain were in $0-50 \mathrm{~Hz}$ range with a resolution of $0.04883 \mathrm{~Hz}$. 


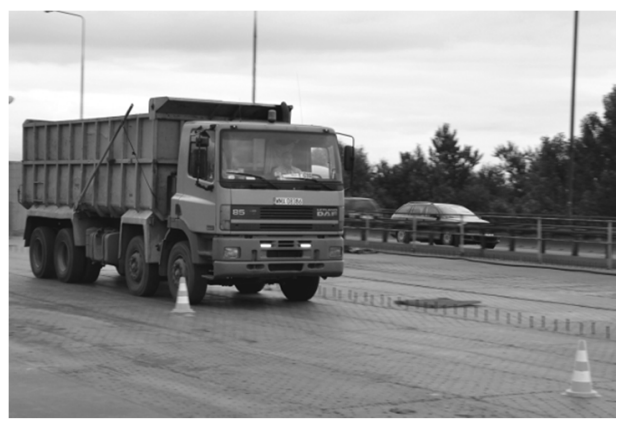

Rys. 2. Samochód ciężarowy wykorzystywany do wzbudzenia drgań mostu

Fig. 2. Passing truck

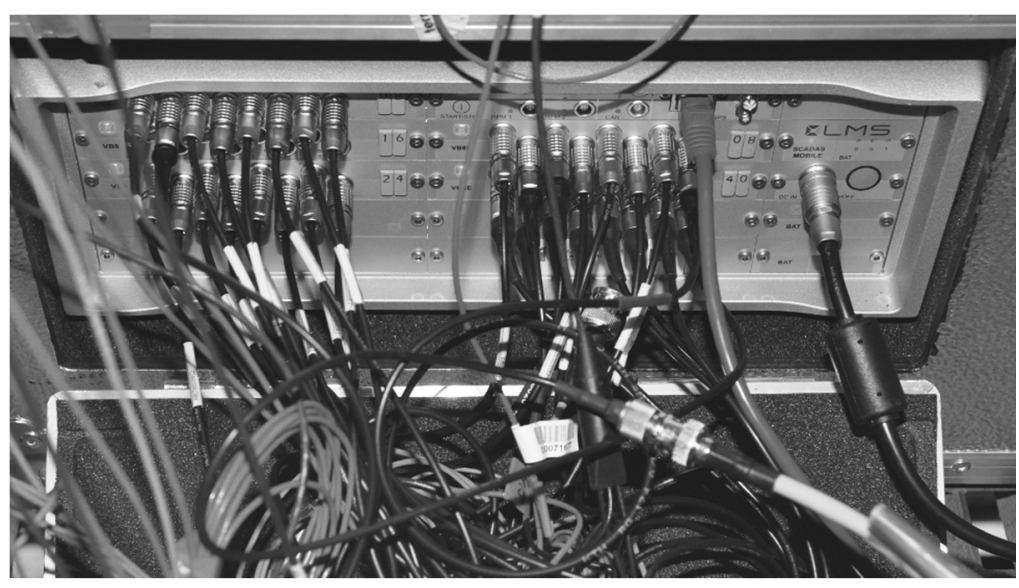

Rys. 3. Wielokanałowyy rejestrator/analizator Scadas Mobile firmy LMS International

Fig. 3. Multi-channel Scadas Mobile signal recorder/analyser by LMS International

The accelerometers applied during measurements were:

- type 1: tri-axial accelerometers (3-D) by PCB Piezotronics, model T356B18, sensitivity $1000 \mathrm{mV} / \mathrm{g}$, measuring range $0.3-5000 \mathrm{~Hz}$,

- type 2: one-axial accelerometers (1-D) by PCB Piezotronics, model T352C03, sensitivity $10 \mathrm{mV} / \mathrm{g}$ measuring range $0.3-15000 \mathrm{~Hz}$

- type 3: one-axial accelerometers (1-D) by B\&K, model 4507 B004, sensitivity $98 \mathrm{mV} / \mathrm{g}$ measuring range $0.3-6000 \mathrm{~Hz}$

- type 4: one-axial accelerometers (1-D) by PCB Piezotronics, model T333B30, sensitivity $100 \mathrm{mV} / \mathrm{g}$, measuring range $0.5-3000 \mathrm{~Hz}$.

Altogether 31 acceleration signals were measured (six 3-D and 18 1-D accelerometers, some 3-D accelerometers were measuring in three and some in two perpendicular directions). 


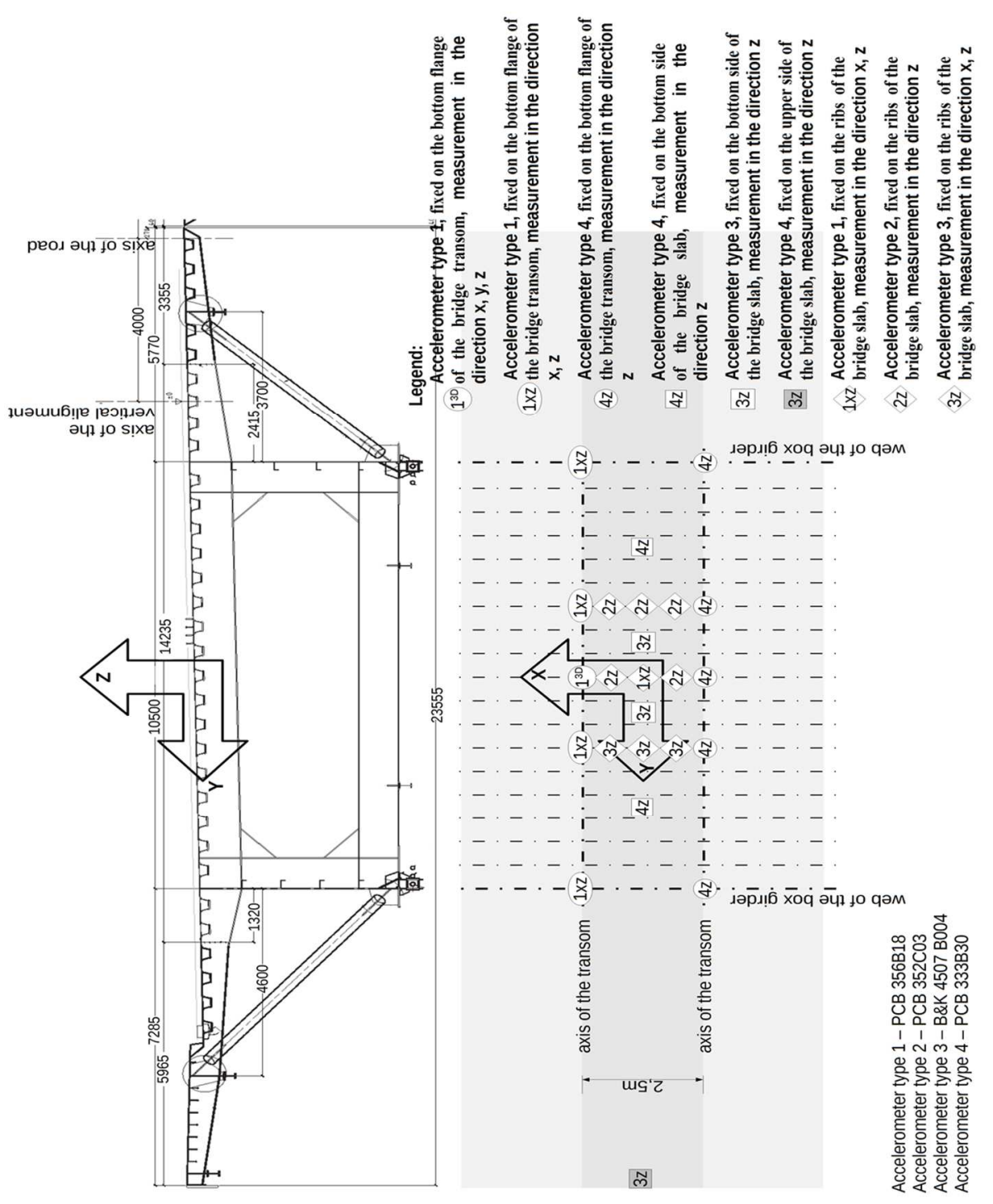

Rys. 4. Rozmieszczenie punktów pomiarowych

Fig. 4. Location of measurement points

\subsection{Location of measurement points}

The vibrations were measured in 24 measurement points (in one, two or three directions) shown in Fig. 4:

- on the bottom flange of the rib of bridge slab (see Fig. 5 and Fig. 6),

- on the bottom flange of the bridge transom (see Fig. 7), 
- on the bottom side of bridge slab (see Fig. 8),

- on the upper side of bridge slab.

Fig. 4 shows, apart from the location of measurement points, also types of adopted accelerometers and measurement directions. The applied set of coordinates X, Y, Z is shown in Fig. 4:

- X direction: horizontal, along the main axis of the bridge

- Y direction: horizontal, perpendicular to the main axis of the bridge

- $\mathrm{Z}$ direction: vertical.

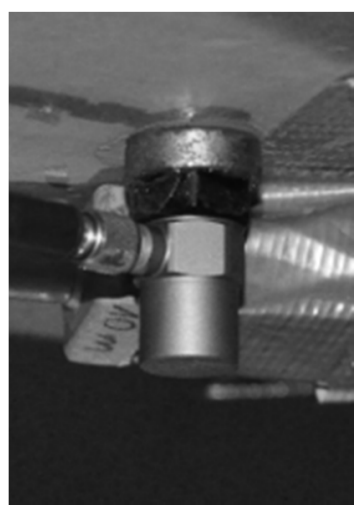

Rys. 5. Jednoosiowy czujnik przyspieszeń zamocowany na dolnej półce żebra

Fig. 5. 1-D accelerometer fixed on the bottom flange of the rib

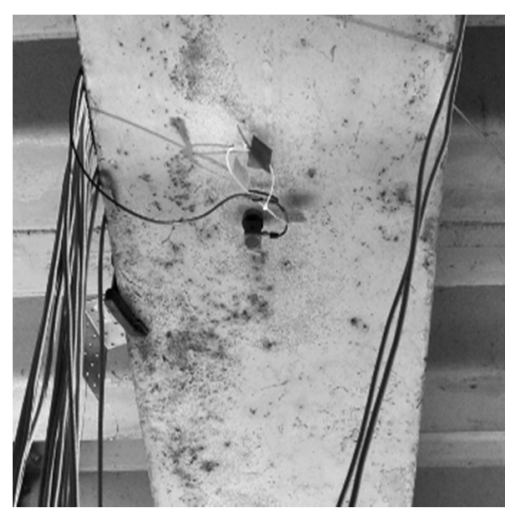

Rys. 7. Trójosiowy czujnik przyspieszeń zamocowany na dolnej półce poprzecznicy

Fig. 7. 3-D accelerometer fixed on the bottom flange of the bridge transom

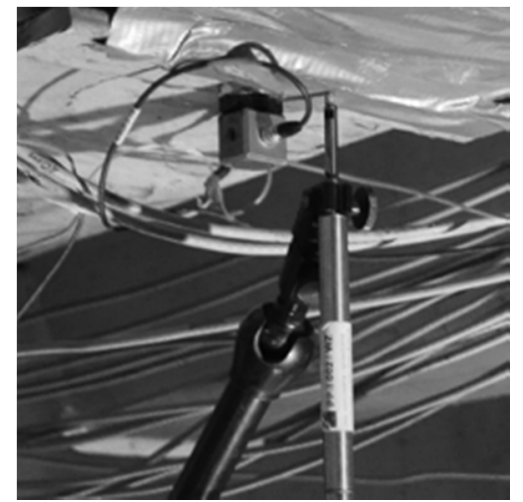

Rys. 6. Trójosiowy czujnik przyspieszeń zamocowany na dolnej półce żebra

Fig. 6. 3-D accelerometer fixed on the bottom flange of the rib

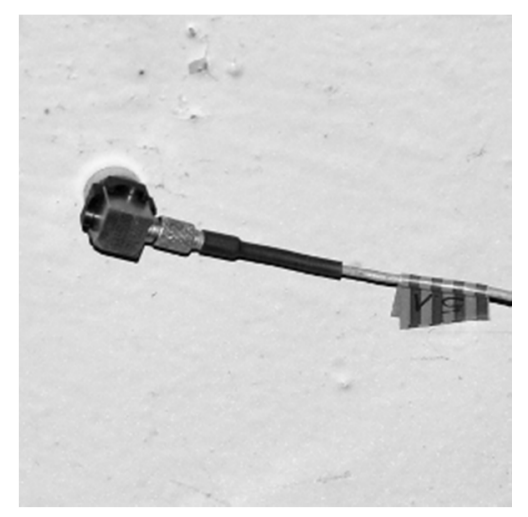

Rys. 8. Jednoosiowy czujnik przyspieszeń zamocowany od spodu płyty pomostu

Fig. 8. 1-D accelerometer fixed on the bottom side of the bridge slab 


\section{Results of modal analysis}

Results of modal analysis for all type of excitation are collected in Table 1. Presented results were obtained using commercial code TestLab by LMS International with PolyMAX algorithm [3, 4]. Modal shape visualizations were obtained for geometrical model of examined element (slab panel, transom) shown in Fig. 9. The first six modes obtained from measurements done during one pass of a truck are presented in Fig. 10 through Fig. 15. The numbering of modal shapes corresponds to Table 1 .

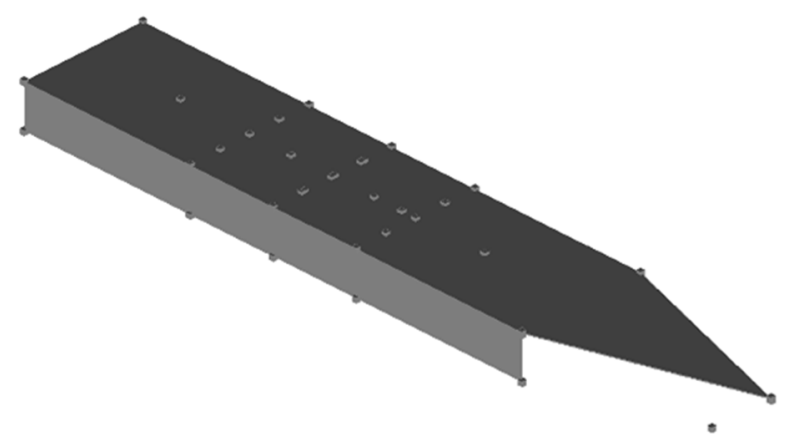

Rys. 9. Model geometryczny

Fig. 9. Geometrical model

The first few modal forms are associated with vibrations of a whole bridge, but in some of them different behavior of ribs can be noticed. The biggest displacements of cantilever are visible in eigenmodes with natural frequencies in the range 12-25 Hz. Above $25 \mathrm{~Hz}$ the horizontal component of vibration of bottom flange of transoms is noticeable.
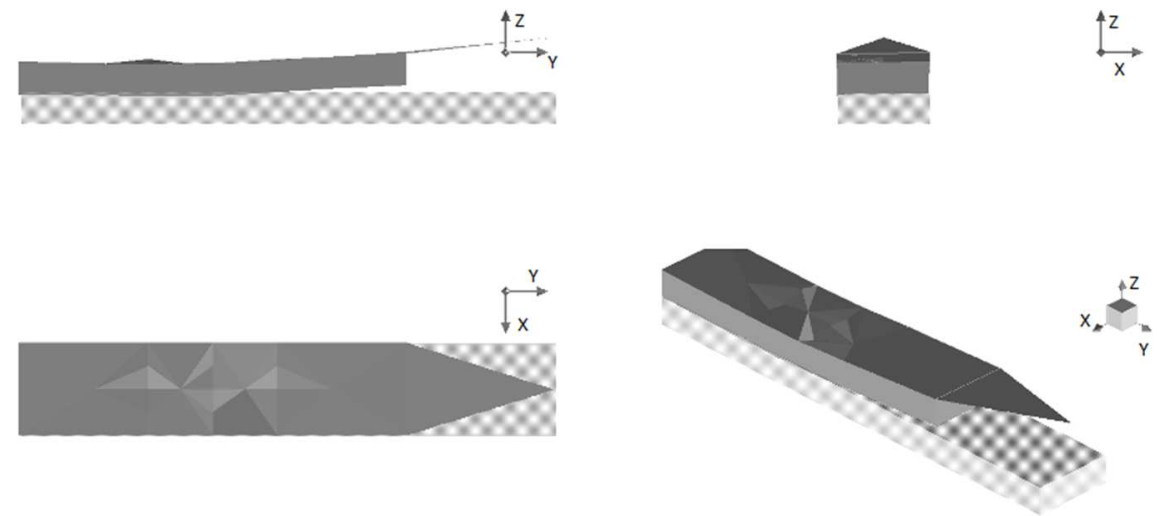

Rys. 10. Pierwsza postać drgań dla $\mathrm{f}=1.40 \mathrm{~Hz}$, maksymalne przemieszczenie w pionie

Fig. 10. First modeshape for $\mathrm{f}=1.40 \mathrm{~Hz}$, maximum displacement in the direction of ,, $\mathrm{Z}$ ” 
Tabela 1. Częstotliwości drgań i współczynniki tłumienia

Table 1. Eigenfrequencies and damping coefficients

\begin{tabular}{|c|c|c|c|c|c|c|}
\hline \multicolumn{5}{|c|}{ Excitation by a truck } & \multirow{2}{*}{\multicolumn{2}{|c|}{ Impulse excitation }} \\
\hline \multicolumn{3}{|c|}{ Single passing } & \multicolumn{2}{|c|}{ All passings } & & \\
\hline No. & $\begin{array}{c}\text { Frequencies } \\
{[\mathrm{Hz}]}\end{array}$ & $\begin{array}{l}\text { Damping coefficient } \\
{[\%]}\end{array}$ & $\begin{array}{c}\text { Frequencies } \\
{[\mathrm{Hz}]}\end{array}$ & $\begin{array}{l}\text { Damping coefficient } \\
\qquad \%]\end{array}$ & $\begin{array}{c}\text { Frequencies } \\
{[\mathrm{Hz}]}\end{array}$ & $\begin{array}{l}\text { Damping coefficient } \\
[\%]]\end{array}$ \\
\hline & & & & & 1,30 & 0,28 \\
\hline 1 & 1,40 & 0,68 & 1,40 & 0,57 & 1,45 & 0 \\
\hline 2 & 2,05 & 0,38 & 2,10 & 0,24 & 2,10 & 0,08 \\
\hline 3 & 2,50 & 0,01 & & & & \\
\hline \multirow[t]{4}{*}{4} & 3,40 & 0,17 & 3,60 & 1,16 & & \\
\hline & & & 4,10 & 0,89 & 4,15 & 0,03 \\
\hline & & & 10,05 & 0,36 & & \\
\hline & & & 12,90 & 0,15 & 12,95 & 1,08 \\
\hline 5 & 13,15 & 0,07 & 13,30 & 0,07 & & \\
\hline 6 & 17,20 & 0,22 & & & & \\
\hline \multirow[t]{2}{*}{7} & 17,70 & 0,11 & & & & \\
\hline & & & 18,75 & 0,08 & & \\
\hline \multirow[t]{2}{*}{8} & 19,45 & 0,23 & & & 19,10 & 0,22 \\
\hline & & & 20,00 & 0,03 & & \\
\hline 9 & 21,40 & 0,47 & & & 21,25 & 0,55 \\
\hline \multirow[t]{3}{*}{10} & 21,70 & 0,07 & 22,00 & 0,18 & 22,00 & 0,53 \\
\hline & & & 22,60 & 0,08 & 22,60 & 0,17 \\
\hline & & & 22,80 & 0,15 & & \\
\hline \multirow[t]{2}{*}{11} & 23,55 & 0,18 & & & & \\
\hline & & & 24,85 & 0,05 & 24,05 & 1,12 \\
\hline 12 & 25,45 & 0,05 & & & & \\
\hline \multirow[t]{2}{*}{13} & 25,70 & 0,04 & 25,65 & 0,15 & & \\
\hline & & & 26,10 & 0,07 & 26,10 & 3,19 \\
\hline \multirow[t]{5}{*}{14} & 26,50 & 0,18 & 26,55 & 0,05 & & \\
\hline & & & 27,15 & 0,18 & & \\
\hline & & & 27,60 & 0,03 & & \\
\hline & & & 28,00 & 0,04 & 28,00 & 0,13 \\
\hline & & & & & 28,55 & 0,92 \\
\hline 15 & 29,00 & 0,01 & 29,55 & 0,18 & 29,30 & 0,44 \\
\hline \multirow[t]{4}{*}{16} & 30,20 & 0,01 & 30,10 & 0,11 & & \\
\hline & & & 31,40 & 0,56 & 31,50 & 2,7 \\
\hline & & & & & 31,55 & 3,09 \\
\hline & & & 31,95 & 0,08 & & \\
\hline \multirow[t]{7}{*}{17} & 32,45 & 0,03 & & & 32,30 & 0,74 \\
\hline & & & 33,35 & 0,04 & 33,30 & 0,48 \\
\hline & & & 34,00 & 0,04 & 33,70 & 0,61 \\
\hline & & & 34,50 & 0,24 & 34,85 & 0,13 \\
\hline & & & & & 34,95 & 0,12 \\
\hline & & & 35,80 & 0,03 & 35,75 & 0,65 \\
\hline & & & & & 36,55 & 0,67 \\
\hline \multirow[t]{5}{*}{18} & 38,55 & 0,06 & 38,50 & 0,04 & 38,35 & 0,7 \\
\hline & & & 39,10 & 0,01 & 39,75 & 0,16 \\
\hline & & & & & 41,10 & 0,89 \\
\hline & & & & & 41,35 & 1,16 \\
\hline & & & & & 41,55 & 0,53 \\
\hline 19 & 42,65 & 0,08 & 42,75 & 0,05 & & \\
\hline \multirow[t]{5}{*}{20} & 42,90 & 0,12 & & & & \\
\hline & & & & & 43,20 & 0,49 \\
\hline & & & & & 44,75 & 0,22 \\
\hline & & & 45,65 & 0,02 & 45,70 & 1,04 \\
\hline & & & 46,60 & 0,01 & & \\
\hline
\end{tabular}




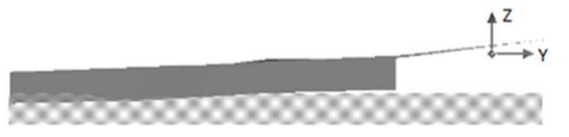

$\stackrel{\iota^{2}}{\longrightarrow}$
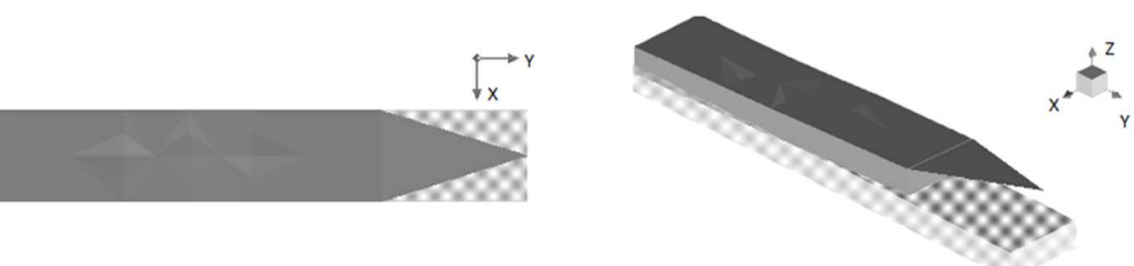

Rys. 11. Druga postać drgań dla $\mathrm{f}=2,05 \mathrm{~Hz}$, maksymalne przemieszczenie w pionie

Fig. 11. Second modeshape, $\mathrm{f}=2,05 \mathrm{~Hz}$, maximum displacement in the direction of ,+Z”
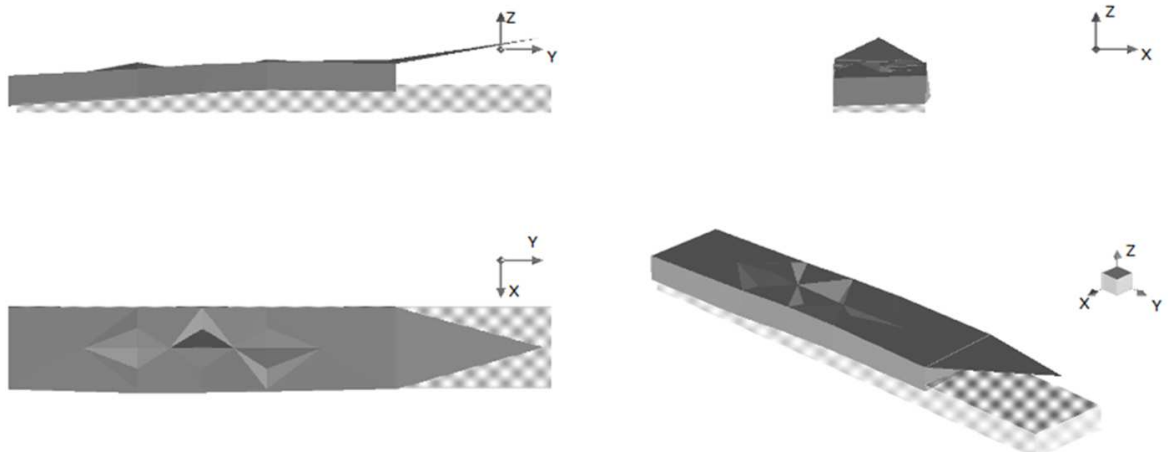

Rys. 12. Trzecia postać drgań dla $\mathrm{f}=2,50 \mathrm{~Hz}$, maksymalne przemieszczenie w pionie

Fig. 12. Third modeshape, $\mathrm{f}=2,50 \mathrm{~Hz}$, the maximum amplitude in the direction of ,, $+\mathrm{Z}$

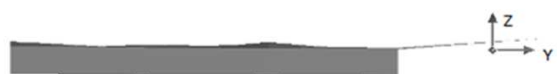

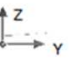

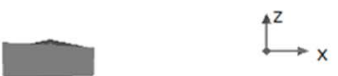

$\$ 00000000000000000000000000$

$\overleftrightarrow{x}$
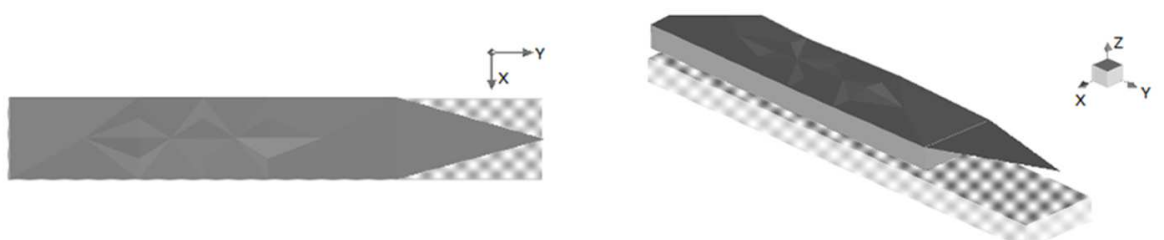

Rys. 13. Czwarta postać drgań dla $\mathrm{f}=3,40 \mathrm{~Hz}$, maksymalne przemieszczenie w pionie

Fig. 13 Fourth modeshape, $\mathrm{f}=3,40 \mathrm{~Hz}$, the maximum amplitude in the direction of , $+\mathrm{Z}$ ” 
$\stackrel{\uparrow^{z}}{\longrightarrow}$

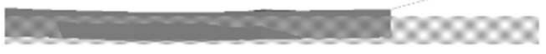

$\vec{x}^{Y}$

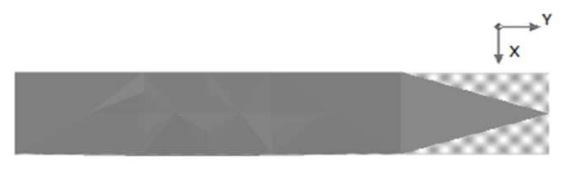

Rys. 14. Piąta postać drgań dla $\mathrm{f}=13,15 \mathrm{~Hz}$, maksymalne przemieszczenie w pionie

Fig. 14. Fifth modeshape, $\mathrm{f}=13,15 \mathrm{~Hz}$, the maximum amplitude in the direction of „,Z”

$\uparrow_{\rightarrow}^{Z} \rightarrow$

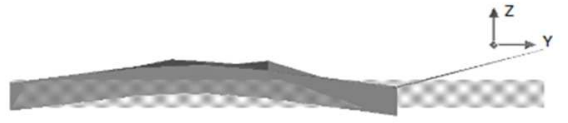

$\underset{x}{\longrightarrow}$

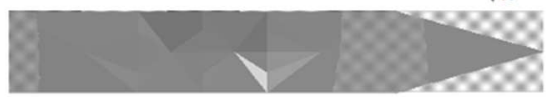

$\stackrel{\stackrel{1}{2}^{\longrightarrow}}{\longrightarrow}$
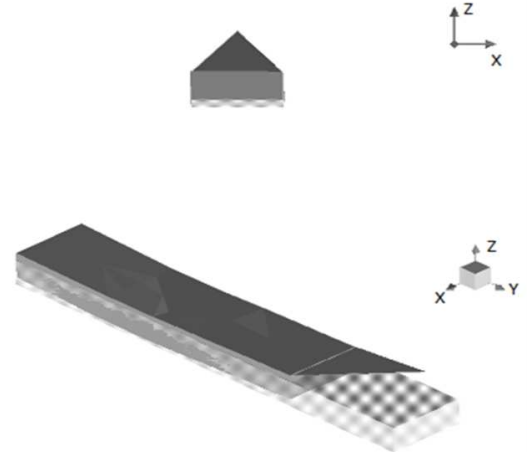

$\stackrel{\mathfrak{l}^{2}}{\longrightarrow}$
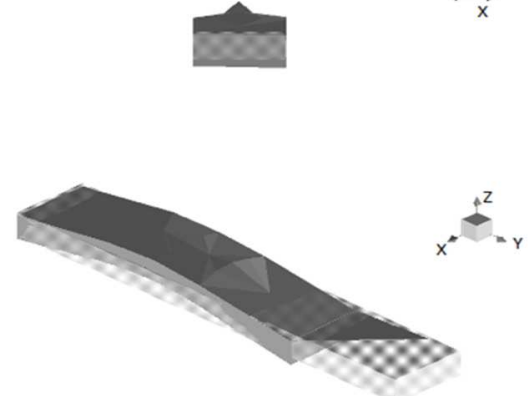

Rys. 15. Szósta postać drgań dla $\mathrm{f}=17,20 \mathrm{~Hz}$, maksymalne przemieszczenie w pionie

Fig. 15. Sixth modeshape, $\mathrm{f}=17,20 \mathrm{~Hz}$, the maximum amplitude in the direction of , $+Z$ ”

\section{Final remarks}

According to the data presented in Table 1 there are some differences of eigenfrequencies obtained from measurements involving impulse excitation and the excitation by a truck.

It should be emphasized, that the measurements were rather complex and the measuring time was limited. The examined structure was only a small part of whole bridge, therefore obtained results in the form of natural frequencies and damping coefficients are now being verified and compared with the numerical model results, but it is clearly visible, that there are some frequencies, in which the cantilever parts resonate. 


\section{Bibliography}

[1] Uhl T.: Komputerowo wspomagana identyfikacja modeli konstrukcji mechanicznych, Wydawnictwa Naukowo Techniczne, Warszawa 1997.

[2] Uhl T.: Lisowski W., Praktyczne problemy analizy modalnej konstrukcji, Wydawnictwo AGO, Kraków 1996.

[3] LMS Test.Lab, The LMS Test.Lab Spectral Testing manual, LMS International 2009.

[4] Bart Peeters, Herman Van der Auweraer: PolyMAX. A Revolution in Modal Parameter Estimation, LMS International, Belgiu.

\section{BADANIA DYNAMICZNE MOSTU GROTA-ROWECKIEGO W WARSZAWIE}

\section{Streszczenie}

W artykule precyzyjnie opisano sprzęt pomiarowy, lokalizację punktów wymuszenia i czujników przyspieszeń wykorzystanych w trakcie pomiarów dynamicznych mostu GrotaRoweckiego w Warszawie (Polska). Zaprezentowane zostały także rezultaty przeprowadzonych badań w postaci form drgań swobodnych i odpowiadających im częstotliwości.

Słowa kluczowe: dynamika, analiza modalna, most stalowy

Przestano do redakcji: 22.02 .2017 r.

Przyjęto do druku: 31.03.2017 r. 